Erratum

\title{
Erratum: Labelle, A., et al. Agent-Based Model for End-of-Life Product Flow Analysis, Resources 2018, 7,42
}

\author{
Alexandre Labelle and Jean-Marc Frayret * \\ Département de Mathématiques et Génie Industriel, École Polytechnique de Montréal, 2900 Boulevard \\ Edouard-Montpetit, Montréal, QC H3T 1J4, Canada; alexandre.labelle@polymtl.ca \\ * Correspondence: jean-marc.frayret@poyltml.ca; Tel.: +1-514-340-4711 (ext. 4930)
}

Received: 12 January 2019; Accepted: 18 January 2019; Published: 21 January 2019

The authors wish to make the following corrections to this paper [1]: On page 11, there are six "(\%)" in the table headers that should be deleted.

The authors would like to apologize for any inconvenience caused to the readers by this change. The change does not affect the scientific results. The manuscript will be updated and the original will remain online on the article's webpage.

\section{Reference}

1. Labelle, A.; Frayret, J.-M. Agent-Based Model for End-of-Life Product Flow Analysis. Resources 2018, 7, 42. [CrossRef]

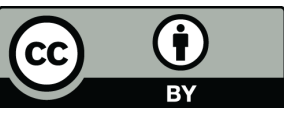

(C) 2019 by the authors. Licensee MDPI, Basel, Switzerland. This article is an open access article distributed under the terms and conditions of the Creative Commons Attribution (CC BY) license (http:/ / creativecommons.org/licenses/by/4.0/). 